\title{
Anatolia
}

\section{Towards a Typology of Community Participation in the Tourism Development Process}

\section{CEVAT TOSUN}

To cite this article: CEVAT TOSUN (1999) Towards a Typology of Community Participation in the Tourism Development Process, Anatolia, 10:2, 113-134, DOI: 10.1080/13032917.1999.9686975

To link to this article: http://dx.doi.org/10.1080/13032917.1999.9686975

里 Published online: 26 Jul 2011.

Submit your article to this journal ¿

LIIl Article views: 1285

Q View related articles $\sqsubset$

4 Citing articles: 26 View citing articles 5 


\title{
Towards a Typology of Community Participation in the Tourism Development Process
}

\author{
CEVAT TOSUN \\ School of Tourism and Hotel Management \\ Bllkent University \\ 06533 Bllkent, Ankara. Turkey \\ E-mail: cevattosunohotmail.com
}

\begin{abstract}
Although the notion of community participation in tourism originates from the general concept of community participation in development studies, the subject of the former seems to have evolved and popularized in isolation from the meaning and scope of its origin. This article reveals that such isolation has ushered in a rigid and simple paradigm of community participation in tourism. This is assumed to be of one form and has universal validity without considering the existence of the different circumstances at various tourist destinations. It is suggested that the concept of community participation should be re-considered in terms of an adaptive categorical paradigm, which incorporates a range of various forms of community participation. These forms of participation are outlined for a variety of abstract situations with the aim of illustrating the legitimacy of different forms of community participation in tourism.
\end{abstract}

Keywords: community participation, tourism development process, and typology.

Cevat Tosun (MSc, Mphil, PhD) is a Visiting Assistant Professor in the School of Tourism and Hotel Management at Bilkent University and Assistant Director of Iskendurun School of Tourism and Hotel Management at Mustafa Kemal University, Turkey. He obtained his Mphil and PhD degrees from the University of Strathclyde, UK. His research interests are aspects of community involvement in tourism development in developing countries, social impacts of tourism, economic contributions of tourism, sustainable tourism development, tourism policy and planning.

Acknowledgments - A previous version of this paper was presented in "Western Social Science Association 42nd Annual Conference, April 26-29, 2000" held in San Diego, California. The author wishes to thank the anonymous reviewers for their helpful comments. 


\section{INTRODUCTION}

Following the popularization of community development projects and community participation in the development process between the 1960 s and early 1980s (Arnstein 1969; Burke 1968; de Kadt 1982; Evers̀ley 1973; Fagence 1977; Inglehart 1971; Pateman 1970; Sewell and Coppock 1977; Smith 1981; United Nations 1975,1981; Verba 1967), an increasing number of tourism studies have focused on arguments for community participation in the tourism development process (TDP). However, the concept of 'community participation' has been used so widely and vaguely that it has become a confusing term in the tourism literature. Moreover, tourism researchers (Blank 1989; D'Amore 1983; Haywood 1988; Inskeep 1994; Jamal and Getz 1995; Keogh 1990; Simmons 1994) fail to provide a conceptual vehicle for policy formulation which explicitly connects the concerns of community participation in the TDP with those of community participation in the development proce 's more generally. The concerns for community participation in the TDP have become too far removed from those of its parental concept, resulting in a considerable gap so that arguments for community participation in the TDP do not necessarily reflect the scope and concern of those participatory development approaches.

The debate on the detailed implications and the interpretation of a participatory development approach (community participation in the development process) still continues. Hence, it seems to be an over-simplification of the issues solely to call community based or community oriented tourism as contributors to the goals of a participatory development approach without further elaboration of what the latter is or should be. In this context, it is unlikely that community based or community oriented tourism research has nothing to learn from the ongoing debate which surrounds the interpretation of a participatory development approach. Those who tussle with the abstract convolutions so characteristic of the general community participation debate might benefit from an example of the implications of their efforts in one particular economic sector, such as the tourism industry.

This article aims at linking, at least theoretically, the concerns of community participation in the TDP with those of community participation in the development process. After reviewing the scope of community participation in the development process, where major areas of debate are highlighted, the paper considers the issues for community participation in the TDP. Many scholars of development studies have suggested that community participation in the development process should be considered as a categorical term that legitimizes a variety of community participation (Arnstein 1971; Burke 1968; Godschalk 1971; Stiefel and Wolfe 1994). In this line, this article also proposes that different forms (active, direct, indirect, passive, etc.) of community participation in the TDP are appropriate under different circumstances in various tourism destinations which are at different level of development. Therefore, community participation in the TDP should not be 
regarded as being within a rigid framework, but rather as an adaptive and flexible paradigm.

It should be noted that community participation is a desired objective in the tourism development process. However, although community participation is strongly linked to some notion of democracy, or democratic rights (involvement, participation and empowerment) in the developed world, it has formidable operational, structural and cultural limitations in many developing countries (Tosun 2000).

\section{SPECTRUM OF PARTICIPATORY DEVELOPMENT APPROACHES}

The term community participation potentially includes a vast area of philosophy, policy considerations, programs, and practical work. Using the concept in such diverse contexts, particular institutional arrangements such as village councils and co-operatives, worker representation in industrial management, social mobilization systems, socially equitable distribution of development benefits, full employment, political and social democracy, good citizenship, structural reform and popular revolution emphasize the importance attached to it but also tends to create confusion (United Nations 1975).

Community participation as a multi-dimensional concept includes representation from many disciplines. Thus, a variety of disciplines such as sociology, political science, planning and social work have dealt with theories and models of the study of citizen participation (Baber 1984; Cole 1974; Florin and Wandersman 1990; Olson 1965; Pateman 1970; Smith 1980; Verba and Nie 1972). Naturally, political scientists, sociologists, engineers, environmentalists, politicians, bureaucrats, and journalists have contributed to the concept of community participation - what it is, what it should be, and how it should be carried out (Schierow and Chesters 1983). Hence, it may be argued that the meaning and scope of any kind of participation may fluctuate depending upon the aims of the users, and the socio-cultural, political and economic conditions in which it is used. This may suggest that the notion of community participation is deeply ideological in that it reflects beliefs derived from social and political theories about how societies should be organized (Midgley 1986).

That is to say, 'community participation is not a simple matter of faith but a complex issue involving different ideological beliefs, political forces, administrative arrangements and varying perceptions of what is possible (Midgley et al 1986: ix). In the words of Stiefel and Wolfe (1994: 17)

\footnotetext{
The studies [of community participation in development] demonstrate the wide differences in rationalities between the social actors engaged in encounters: politician, technocrats and bureaucrats, military and police officers, national and local elites, employers, ideologists, religious leaders, academic figures in different disciplines, students, national and local leaders of popular organizations, the rank and file of these organizations, and the unorganized masses of the excluded. These actors often seem to be following scripts in separate, incompatible dramas, indifferent to or contemptuous of one another.
} 
The above discussion suggests that community participation in the development process should not be regarded as taking place within a rigid framework. That is to say, community participation is not a monolithic term but consists of many different approaches (Pacione 1988).

As most scholars note, the term community participation is elusive, ambiguous, tricky, broad, subject to many interpretations and multiple definitions (Chetkov-Yanoov 1986; Dudley 1993; Godschalk 1971; Law-Yone 1982; Morgan 1993; Oakley 1991; United Nations 1975, 1981). That is to say that 'no clear consensus exists as to what is meant by community participation, with the diversity of definitions reflecting the ideological range of interpretations of development and different approaches to planning' (Moser 1989: 81). The conceptual anarchy regarding community participation may imply that 'each term is ambiguous, multivocal, and vaguely defined' (Morgan 1993: 6 quoting Geertz 1973:195); 'its meanings change depending on who is using it and what interests they are promoting' (Morgan 1993: 6). Thus, there is disagreement among members of any discipline on the nature of the issues that they examine (Hillery 1955). In this context, Partridge (1970) argued that one of the most distressing elements in the discussion, particularly from the viewpoint of the participant, and the students of the subject, is the deficit of consensus on the definition of participation. To Fagence (1977), this definitional void is the basic cause of the unsatisfactory state of participation theory, and is contributory to the generally less than satisfactory state of the practice.

In brief, 'as a popular concept, citizen participation has come to be an umbrella term, encumbered by so many associations that its precision has been lost' (Godschalk 1971:9). Thus, it is impossible to do justice to the complexity of considerations bound up with the term community participation, which is as old as government itself, in one single document. As implied, the concept of participation does not permit a universally valid definition since it is used so widely and its scope is so comprehensive, that it is impossible to encapsulate within one definitive term (Cohen and Uphoff, 1980; Lisk 1985a; Oakley 1991; Oakley and Marsden 1984). Explicitly, community participation is seen as a concept, which cannot be defined in a single definition, thus, it must be explained by approaching it from different points of view. According to this view, the form of community participation is determined by various conditions such as the political, socio-cultural and economic structure of the place where participatory planning approach is intended to be implemented.

The above argument reveals that confusion and vagueness seem to predominate concerning the operational meaning of community participation that may take divers forms and which range along a continuum. At one end, it can initiate participatory movement at the grassroots level without technocrats' sponsorship; at the other, professionals and politicians impose it by structuring the organization. It can vary from minimal forms involving information exchange (surveys, handouts, questionnaires, and the like) to full 
forms of community control (Arnstein 1971; Burke 1968; Law-Yone 1982; Willis 1995). Hence, as UN (1981: 5) emphasized, the term community participation 'can best be understood in the context of a specific country and its political and socio-economic system'. This suggests that the question of participation should not be approached 'in the terms of single suggestions or universal formats, but rather in terms of those values and rights which attempts to implement participation should emphasize' (Cahn and Cahn 1971:39)

It may now be recognized that 'for the traveller approaching the rocky road of citizen participation, there is no prescribed route, but the road signs and warnings are many and distinct' (Wilkins and Passett 1971: 6). In this vein, a typology of community participation may function as the signs and warnings on the road. The following typology of community participation may lead us to consider the concept of community participation as a categorical term. In other words, this typology suggests that community participation in the development process takes different forms ranging between citizen power to manipulation (see Arnstein 1971; Hughes 1985; Stiefel and Wolfe 1994) based upon circumstances under which it will be formulated and implemented. Evidently, not every kind of participation is appropriate for every kind of objectives (Chetkov-Yanoov 1986).

This typology may reduce the conceptual anarchy prevailing in current participatory development studies and enable us to distinguish different forms of community participation in the development process. Adaptation of this typology of community participation to tourişm may open a muchneeded debate on the scope and meaning of a participatory development approach, and question the legitimacy of current participatory discussions in the tourism literature. Moreover, it may encourage tourism research to benefit from the accumulated knowledge and experience of community participation in other fields from where the participatory development approaches originated.

\section{Typology of Community Participation}

The participatory development approach has appeared in international development repeatedly though it has been called by different terms and woven into the development process in different ways (Stone 1989). More explicitly, there are divergent ideas on types of community participation and different experts have classified the same concept under the same scope but with different names. Thus, it is possible to examine types of community participation under many headings. However, it has been preferred to classify it under three main headings following the implication of UN (1981) and Morgan (1993). These are: 1) spontaneous participation, induced participation and coercive participation (see Table 1). 
Table 1. A Simplified Typology of Community Participation

\begin{tabular}{|l|l|}
\hline $\begin{array}{l}\text { TYPE OF COMMUNITY } \\
\text { PARTICIPATION }\end{array}$ & DEFINING CHARACTERISTICS \\
\hline SPONTANEOUS & $\begin{array}{l}\text { Bottom-up; active participation; direct participation; participation in whole process } \\
\text { of development including decision making, implementation, sharing benefit ond } \\
\text { evaluating; authentic participation; coproduction; self planning; wide participa- } \\
\text { tion; social participation. }\end{array}$ \\
\hline INDUCED & $\begin{array}{l}\text { Top-down; passive; formal; mostly indirect, represents degree of tokenism, ma- } \\
\text { nipulation and pseudo-participation; participation in implementation ond shar- } \\
\text { ing benefits; choice between proposed olfernatives and feedback. }\end{array}$ \\
\hline COERCIVE & $\begin{array}{l}\text { Top-down, passive; mostly indirect, formal; participation in implementation, but } \\
\text { not necessarily sharing benefit;; choice between proposed limited alfernatives or } \\
\text { no choice; represent poternalism, non-participation, high degree of tokenism } \\
\text { ond manipulation. }\end{array}$ \\
\hline
\end{tabular}

Sources: Derived from the literature in development studies

\section{Spontaneous Participation}

Spontaneous participation is voluntary, base-up without external support. It represents an ideal mode of participation, as it mirrors a voluntary and autonomous activity on the part of people to handle their problems without government's or other external agencies' help (UN 1981). This type is also referred to in the developmental literature as informal (Sherraden 1991), bottom-up (Rajakutty 1991; Wolfe 1982), 'community supportive' (Morgan 1993:5 quoting Werner 1976), social participation (Morgan 1993: 5 quoting Muller 1983), wide participation (Morgan 1993 quoting Rifkin et al 1988), active participation (Cheema 1987; Santhanam 1993; UN 1975), authentic participation (Midgley 1986b; Wolfe 1982) or self-planning (Wandersman 1981). It may also represent a degree of community power in Arnstein's (1971) ladder of citizen participation.

Although the above terms for spontaneous participation are used interchangeably to a large extent, to explain some of them in further detail may help to manifest some other dimensions of this kind of participation.

Active participation: It takes place when its purpose and content clearly originate with people themselves. People feel that they are acting as a free agent rather than under any duress or pressure, or as a result of manipulation or deception (UN 1975). It is assumed that the active involvement of people on the basis of their free will in decision making can contribute more fully to the intended development (Cheema 1987). In other words, it is 'the collective effort by the people concerned to pool their efforts and whatever other resources they decide to pool together, to attain the objectives they set for themselves' (Santhanam 1993: 419 quoting ACC Task Force on Rural Development 1978). 
Direct participation: It involves physical interaction and a face-to-face relationship between those persons in whom a community has vested the authority to make decisions and the people affected by those decisions (Richardson 1983; UN 1975). Direct participation in decision-making does not automatically imply membership of a decision-making body (Richardson, 1983). In other words, direct community participation does not necessarily mean to delegate decision-making power to those people who will be affected by any decisions made. Hovewer, the community has the opportunity to directly convey its message regarding developmental issues to the decisionsmakers.

Informal participation: It is 'unofficial or unsanctioned'. It takes place in unstructured and unofficial day to day interactions between community development staff and members of local communities or between local leaders and community development staff. Informal community participation occurs outside the formally designated structure of participation. It takes many different forms and varies widely throughout communities. Thus, it is not easy to define and quantify (Sherraden 1991).

The concept of informal community participation originates from the workings of informal organizations, polities, and economies (Le Vine 1989 cited in Sherraden 1991). It has been argued that the informal realm runs semi-autonomously, and frequently in opposition to official and formal organization (Sherraden 1991 quoting Scott 1985; de Soto 1989; Skalnik 1989). To Sherraden (1991), informal community participation affects implementation of local development programs, and, in addition, has significant effects on policy development.

Authentic participation: The term authentic participation is ambitious. Few proponents in this field have recognized the formidable difficulties in fully involving all members of the community in all aspects of development and equally few have become aware of the practical problems of advocating full autonomy over local affairs (Midgley 1986b). Authentic participation mirrors movements of the grass-roots. It is not imposed from above; it is a demand of the community to be responsible for and to decide its own affairs. It lays emphasis on distribution becoming a means of obtaining a larger share in the fruits of development and heightens the participants' awareness of their own capabilities to make choices and influence the content and outcomes of development (Midgley 1986b quoting UNRISD 1980). Authentic participation necessitates profound social structural change and a massive redistribution of social-political and economic power (Pearse and Stielfel 1980). Moreover, It represents 'the involvement of the poor which will not only need a change in domestic political institutions but a change in the international economic order' (UN 1981: 9).

Therefore, it has been observed that the performance of authentic participation is not encouraging, and in fact it seldom occurs. 


\section{Induced Participation}

Towards the other end of the continuum, induced participation is sponsored, mandated and officially endorsed. This type is the most common mode to be found in developing countries since, in many developing countries, government has a central role to initiate participatory action and institutionalize it. This has been done through such strategies as motivating and training local leaders to assume leadership roles, building self-management and cooperative organizations, and supporting civic and community bodies (UN 1981).

Induced participation is also called formal (Sherraden 1991), top-down (Morgan 1993; Wolfe 1982) passive participation (Santhanam 1993; UN 1975) or pseudo-participation (Midgley 1986; Wolfe 1982). To explain those terms which are used interchangeably for induced participation may contribute to an understanding of the typology of participation in a wider sense.

Passive participation: 'The idea of passive participation involves the people in actions that have been thought out, designed and controlled by others (Santhanam 1993: 419). Passive forms of participation occur where people are merely involved in the implementation of decision about which they were not consulted. Thus, their participation is passive (UN 1975).

Indirect participation: It refers to modes by which a community takes part in participatory activity, but is not experiencing personal, and face to face interaction with official spokespeople (Richardson 1983). People's opinions are conveyed to those individuals in whom the community vests responsibility for making decisions through institutionalized and episodic channels of communication. At one extreme, demonstrations, boycotts and other forms of mass action and at the other extreme public opinion polls (which can be used to assess how a community feels about vital issues) or referenda are means of indirect participation. Another form of indirect participation occurs when people react to problem situations on an individual basis through writing letters, signing petitions, attending legislative and administrative hearings, or taking resource to judicial proceedings. In the center of indirect participation are representative institutions, through which a community is represented on a group basis via popularly elected legislatures, trade union and peasant union federations, interest groups and political parties (UN 1975).

Formal participation: It is officially structured and sanctioned. Rules and content of participation are determined by government. Though formal community participation activities have an important impact on local program implementation, it has only limited influence on policy design and development (Sherraden 1991).

Pseudo-participation: It refers to a kind of participation of a community in implementation or the ratification of decisions already taken by external bodies (Midgley 1986b). The typical African co-operative whose statutes, internal regulations and modes of operation have been predetermined by government 
officers with whom people in local community may not agree is an example of pseudo-participation (Bugnicourt 1982).

\section{Coercive Participation}

At the extreme end is coercive participation which is compulsory, manipulated and contrived (UN 1981). It is also named as community oppressive (Morgan 1993 quoting Werner 1976) and narrow participation (Morgan 1993 quoting Rifkin et al 1988).

Coercive forms of participation, although sometimes indistinguishable in form from the induced type may, at least in the short term, yield immediate results; in the long run, community participation that is forced and lacking in public support will turn out to be counter-productive and erode community interest in becoming involved in development activities (UN 1981).

Clearly, these three main categories of community participation in the development process represent a broad typology of community participation. As illustrated earlier in Table 1, each of these categories contains various forms of community participation. However, it seems to be very difficult to put a definite border between these forms of community participation in each broad category.

As can be noticed, the scope and meaning of coercive and induced participation are very close each other. As shown in Table 1, coercive participation represents higher degree of tokenism and manipulation than induced participation. Thus, it is also called non-participation. Spontaneous participation requires a community to participate in the whole process of a development project including decision making, implementation, sharing benefit and evaluation. Whereas induced participation represents the involvement of a community in the implementation and in sharing the benefits of development projects. However, coercive participation needs a community to be involved in solely the implementation process of a development project, but not necessarily sharing the benefits. There are no real alternatives for a community to choose between in the case of coercive participation.

The categorization of community participation may enable us to understand participatory development activities in a better way in the real world by distinguishing various forms of community participation from each other. Hence, this typology seems to have contributed to conceptual clarity of the term 'community participation' in the tourism literature.

The implication of the noted typology of community participation is that different interpretations of community participation in the TDP are appropriate under different circumstances. In this vein, community participation in the TDP should be regarded as an adaptive and flexible paradigm which allows us to legitimize various forms of community participation in the TDP ranging between authentic participation to non-participation according to site-specific circumstances. 


\section{Tourism and the Participatory Development Approach}

One may expect that tourism researchers should have a leading role in the debate concerning the meaning and implications of community participation in the development process since 'the most noticeable and dramatic consequences of the tourism system occur at the tourist destinations' (Leiper 1990: 23). It is projected that tourism will continue to grow at a faster rate than the average growth of the world economy, and will become the largest industry in the world economy (the World Travel and Tourism council (WTTC) 1995). More explicitly, the way tourism development takes place has a great effect on host communities who have substantial roles in sustainable tourism development. Thus, it appears to be inconceivable to isolate these host communities from tourism development. But, it seems not to be the case. The review of the tourism literature on the participatory tourism development approach suggests that there is no agreement among scholars on what the term means. They have used interchangeably different phrases such as community involvement in tourism (Murphy 1983), community-responsive tourism (Haywood 1988), residents responsive tourism (Ritchie 1993; Ryan and Montgometry 1994), community participation in tourism (Simmons 1994; Tosun 2000), public participation in tourism (Keogh 1990), community approach to tourism (Murphy 1985), community driven tourism (Prentice 1993), community-based tourism, community-oriented tourism (Blank 1989) and community collaboration in tourism (see Jamal and Getz 1995) to explain the participatory tourism development strategy. Using the concept of community participation in this way has tended to reduce its usefulness for scientific communication and precision. The conceptual vacuum regarding the participatory tourism development approach reflects 'the view that concepts do not have real or set meanings which can lead to conceptual anarchy, a problem with no entirely satisfactory solution' (de Vaus 1996: 48).

Moreover, most proponents of participatory tourism development advocate it without elaborating in detail what community participation is or should be. Perhaps, this is due to the fact that community participation is a sitespecification activity determined by circumstances at the site. But, a theoretical framework based on a typology is still needed, on which the sitespecific participatory action should be developed. Although some researchers in tourism have put forward several models for community participation in the TDP (Gunn 1988; Hall 1994; Hall and Jenkins 1995; Murphy 1985), the theoretical underpinnings of such efforts remain weakly developed.

However, more recently, there seem to be significant efforts to introduce and adapt organizational and management theories, and power relation theories to a tourism context (Jamal and Getz 1995; Reed 1997; Selin and Beason 1991). Although those recent efforts have provided further insights for and made viable contributions to understanding the participatory tourism development approach, a re-connection with participation theories is still not 
satisfactory. Research on participatory tourism development has emerged to a large extent in isolation from general participation theories. Focusing on arguments for the participatory tourism development approach may give a clearer picture in this regard.

It is stated that, 'the industry uses the community as a resource, sells it as a product, and in the process affects the lives of everyone' (Murphy 1985: 165). Thus, 'the people who must live with planning decisions should be involved in their formulation' (Rosenow and Pulsipher 1979: 81) and the community's interests must be defended (de Kadt 1979). It is contended that the destination community is an important component of the tourism product (D'Amore 1983; Murphy 1983), and, thus, 'successful tourism development depends on strong community support' (Getz 1983: 87). It is assumed that participation of host communities in the TDP will increase the effectiveness and efficiency of an implementation of tourism development plans (Inskeep 1991).

It has been advocated that community participation in the TDP contributes to achieving sustainable tourism development (Joppe 1996; Inskeep 1994; Taylor 1995; Tosun and Jenkins 1996). In this context, it is stated that '... a reasonable degree of consensus is needed for long term success' of tourist destination' (Ritchie 1988: 199). Thus, 'an important aspect of sustainable development is emphasizing community-based tourism. This approach to tourism focuses on community involvement in the planning and development process' (Inskeep 1994: 8). It is also suggested that the limits of local tolerance to tourism can be increased through participation by locals in the tourism development process, thus social carrying capacity can be increased as well (D'Amore 1983), which is defined as 'that point in the growth of tourism where local residents perceive, on balance, an unacceptable level of social disbenefits from tourist development' (D' Amore 1983: 144). On the other hand, it may be assumed that involvement of the local community can be a tool to maintain unique lifestyles of host communities, fulfill residents' aspirations and prevent alteration of the qualities of a given area to suit tourist expectations, which is needed to achieve sustainable development through environmentled tourism (Hunter 1997; Tosun 1988).

Proponents of community participation in tourism have claimed that for desired guest-host relationships '... a participatory approach to tourism planning is of the utmost importance' (Haywood 1988: 117) since it is implicitly presumed that community participation will ensure both tourists' and host communities' satisfaction. It is argued that 'while all scales of planning are important for tourism development, planning at the community level is vital if any region wishes to deliver tourism experience which ensure both visitor satisfaction and ongoing benefits for the residents of destinations areas' (Simmons 1994: 99).

In this context, the International Institute of Tourism Studies (1991:9) has reported that 'there is a need to recognize that tourism must benefit the local 
community and that there must be broad-based participation in tourism development decisions at the community level'. It has been implied that community-based tourism development should give better opportunities to host communities who seem not to be armed to yield the benefit from a tourism industry which has been driven by market forces (Brohman 1996; Keogh 1990; Murphy 1985; Simmons 1994)

On the other hand, community participation in the TDP has been advocated since it is expected to help tourism planners prepare better tourism plans. For example, Inskeep (1988: 370) states that 'the planners or the government should involve the residents in the decision making process of developing tourism and give them sufficient opportunities to receive its benefits through employment at all levels, easy access to tourist facilities and attractions, and equity ownership of facilities and services'. In this context, it is also argued that 'central to this community-driven tourism planning is an explicit recognition that experts cannot judge the perceptions, preferences or priorities of host communities' (Pearce et al 1996: 10-11). What the George Washington University International Institute of Tourism Studies (1991: 9) has stated in its assembly report of 'Policy Issues for the 1990's' is in line in this regard: 'resident responsive tourism is the watchword for tomorrow: community demands for active participation in the setting of the tourism agenda and its priorities for tourism development and management cannot be ignored'.

Moreover, it is stated 'the public's right to participate in the planning of activities that affect their daily life is now a widely accepted principle throughout the democratic world' (Simmons 1994: 99). Thus the tourism planning process should lead to the participation of various groups from social classes that represent the diverse interests of the broader community. In the developing world 'this would not only discourage undemocratic, top-down decision making, but also provide opportunities for communities to use their own resources and popular creativity to find locally appropriate methods of tourism development' (Brohman 1996: 61). On the other hand, since planning has a time dimension, planning by a public authority within a community can become very difficult because of changes caused by elections. 'This leads further support to the need to involve residents and other key stakeholders into flexible and dynamic planning process that can sustain the changing administration and adjust to other forces impacting on the tourism system' ( $\mathrm{ga}$ mal and Getz 1995: 199).

It is noticed that arguments for community participation in the TDP have emerged at the normative level and assumed only one form of community participation in the TDP, which has universal validity. The discussion on community participation in the TDP also shows that there is a tendency among tourism researchers to avoid detailed theoretical analysis of community participation. Hence, it is very common to find tourism studies in which community participation in the TDP is mentioned but never explained, or participatory tourism development is addressed in a vague way by em- 
phasizing its necessity for a better tourism development with normative statements and catch-words.

The following typology of community participation in the context of tourism may lead us to clarify the term community participation in a better way by legitimizing various types of community participation in the TDP under the assumption of existence of different circumstances in each host community. Moreover, the adaptation of community participation as a categorical term from development studies to tourism may improve the theoretical basis of community participation in the TDP.

\title{
Towards a Typology of Community Participation in the TDP
}

Implicit in those studies is that there is only one type of community participation which is assumed to have universal validity at all levels (local, regional and national) without considering site specific circumstances under which it would be formulated and implemented. Simmons's argument appears to be exceptional in this regard. He (1994: 100) argued that

\begin{abstract}
It has become apparent that different techniques will address different objectives for participation and different styles and stages of planning. No technique can fulfill alone the requirements of participation and a 'staged approach', using a variety of techniques, will be required as planning moves from normative (policy) to an operational context.
\end{abstract}

However, he also seems to have failed to adopt community participation as a categorical term to the tourism development process.

Acceptance of community participation in the TDP as only one form is easy, but it is naive to claim its overall applicability in different tourist destinations under different conditions. Many aforementioned authors appear to use different phrases as a perfect substitution for the term 'community participation' with no explicit references to the forms of participation. Obviously, this may illustrate a disconnection and isolation of tourism studies from participatory studies in general.

In the context of the preceding debate on the forms of community participation, such lack of detail and clarity appears increasingly inadequate. In the real world, it is impossible to formulate a participatory tourism development approach and then to implement it in all tourist destinations which have different levels of development, socio-political, economic and cultural structures. That is to say, local tourist destinations at different stages of development have unequal potential opportunities and challenges for the participatory tourism development approach. This may explain why there should not be a general model or mode for community participation in the TDP. Hence, forms of community participation in the TDP should vary from one tourist destination to another according to circumstances, which requires a typology of community participation in this regard. However, the need for such flexibility has not emerged to engage with the full spectrum of views on community 
participation in the tourism development process. In this context, this article is an effort to achieve such flexibility. The reader is here reminded that categorization of community participation in the TDP is not an attempt to develop a universally valid participatory tourism development model, rather it is an effort to contribute to further conceptual clarity, which may improve the theoretical framework of a participatory tourism development strategy.

Finding appropriate forms of community participation in the TDP according to the characteristics of the destination community cannot be achieved without explaining details of forms of community participation. Perhaps the most appropriate way to perceive community participation in the TDP is to search for an over-arching paradigm within which several different forms of participatory tourism development approaches can be legitimized according to the holistic features of the host destinations. What is important, is that the participatory tourism development approach should not be conceptualized as one form only.

In this vein, several participatory tourism development approaches, based loosely on a typology of community participation in general, can be outlined although it is not easy to consider all possible types of community participation in the real world. These are advanced here with the hope of stimulating debate, rather than as a solid prescription. All of these approaches are predicated on the belief that a participatory tourism development approach should not be of only rigid one form. Indeed, developing a typology of community participation in the TDP is needed to analyze and understand the concept in a more systematic way so as to improve the conceptual framework for participatory tourism development approach.

1- Pseudo Community Participation in Tourism Development: This form of community participation in the TDP may be seen as going as far as is possible towards non-participation that has been contrived as a substitute for genuine participation. The real objective is not to enable people to participate in the tourism development process, but to enable power holders to educate or cure host communities to turn away potential and actual threats to future tourism development. Some decisions may be taken to meet basic and feltneeds of host-communities by consulting local leaders so as to reduce sociopolitical risks for tourists and tourism development. Therefore, phrases such as community-oriented tourism development, community-based tourism development used in the tourism literature may be classified under the pseudocommunity participation in the TDP.

Although it seems that tourism development is to take place based upon host communities' priorities, it is heavily skewed towards the fostering and development of tourism, and would primarily be concerned with meeting the needs and desires of decision makers, tourism's operators and tourists. This form of participation does not give any opportunity to host communities to have a voice in the decision making process of tourism development. 
It is unlikely that this form of community participation will ensure host communities' satisfaction and create a reasonable degree of consensus needed for the long term success of tourist destination. It is not a long-term strategy for developing tourism in a sustainable manner, but a short-term policy to achieve non-communal objectives. It may be detrimental to tourism development in the long-term when host communities realize that their known needs are ignored due to patron client relations between the decision-makers and tourism operators.

Moreover, pseudo-community participation in the TDP is top-down and mostly indirect. It does not require the participation of all members of a host community in a tourist destination. Mostly, it takes place through motivating and training local leaders to participate in implementation of tourism development projects. These local leaders mostly are from local elites who act as agents of central government to facilitate the implementation of centrally made decisions at a regional and local level. This type of community participation is the most common mode to be found in the developing world where government has an important role to initiate tourism development and establish the institutional structure for it. Therefore, tourism development in developing countries is driven by priorities of central governments, rather than by the needs of indigenous local people who usually have no choice except for living with what conditions are determined for them. Pseudocommunity participation may represent one form of induced and coercive community participation in the developmental literature (see Table 1).

2- Passive Community Participation in the TDP (Passive Participatory Tourism Development): Passive participatory tourism development may involve host communities that only endorse decisions regarding tourism development issues made for them rather by them, or host communities merely involved in the implementation of decisions in which they have no voice. The contribution of host communities to tourism development is limited to their performing assigned tasks. It may refer to a kind of host community participation in implementation or the ratification of decisions already taken by external bodies. Thus, host communities are not decision-makers, but decision-takers (decision-implementers) in relation to tourism development issues in their localities.

Host communities can be used as instruments for the attainment of specific ends; such as protecting stability and changing attitudes of host communities (Burke 1968; Godschalk 1971). Additionally, formal bodies may aim at obtaining information about socio-cultural features of host communities and providing some information to them as well, which is needed to increase the efficiency of decision-makers to achieve their ultimate goal.

Mostly, host communities take part in tourism development issues, but not experiencing personal, face to face interaction with decision-makers. Systematic community consultation activities such as open public meetings and for- 
ums are performed through an appointed task force. It creates an opportunity for host communities to convey their feelings and opinions regarding tourism development issues indirectly to decision-makers. Passive forms of community participation in the TDP actually represent some forms of induced participation such as top-down, indirect or a degree of tokenism and manipulation in the developmental literature.

3- Spontaneous Community Participation in Tourism Development: This form of community participation in tourism can vary from direct community participation without decision-making powers to authentic community participation as community power. It originates from motivation and the needs of host communities. The implication of spontaneous participation for tourism development can take many forms as they have been discussed in the developmental literature such as direct, active, authentic, etc. To explain some of them in the context of tourism development may contribute further to conceptual clarity.

Direct host community participation in the TDP: It requires a face-to-face communication between decision-makers and destination communities who will be/are affected by the type and scale of tourism development in their territories. It gives host communities ample opportunities to directly convey their feelings and opinions regarding tourism development. However, it does not necessarily delegate decision making power to those host communities who will be affected by decisions made, but it may be the first step towards active community participation in the TDP. The final outcome of this type of participatory tourism development largely depends upon the sincerity of the decision-makers in responding to the host communities' needs and wants, and the ability of host communities to express themselves.

Active community participation in the TDP: It refers to host community participation in the TDP based on their own desires and motivations to achieve their goals determined by themselves without external pressure. Active participation of host communities requires financial and personal commitment of local people in tourism development on day-to-day as well as long-term development projects of tourism. Efficiency and effectiveness of active community participation in the TDP largely depends upon availability of financial resources at community level, and the quality and quantity of human resources with entrepreneurial skills.

In the case of active community participation, local people in tourist destinations participate in the whole process of tourism development including decision making, implementation, sharing benefit, monitoring and evaluation of tourism development programs. It does not necessarily require the participation of all members of a host community, rather participation of local people with entrepreneurial skills as investors, participation of local leaders including elected, informal and appointed, and the participation of local people as employees in the TDP may be sufficient for effective active community participation. 
Authentic host community participation in the TDP: It places emphasis on distribution becoming a means of obtaining a larger share in the fruits of tourism development and heightens the host communities' awareness of their own capabilities to make choices and influences the content and outcomes of tourism development. Host communities can enter into a partnership that enables them to negotiate and engage in a trade-off with traditional power holders. Moreover, host communities may have a voice in the decisionmaking process of tourism development and have full managerial power over tourism development. This form of community participation hardly exists in the real world, particularly in developing countries.

In the case of authentic community participation in the TDP, host community participation is not a means, but an end itself. Thus, the process and mode of participation seem to be more important than the final output of the participation. In other words, it refers to a process the outcome of which is meaningful participation (Oakley and Marsden 1984). Hence, host community participation as an end is the inexorable consequence of the process of empowering and liberation. The state of achieving power and of meaningful participation in the TDP is in fact the objective of the exercise. Therefore, it is not easy to perceive. The end itself becomes difficult to determine in definite terms since it is related to the qualitative processes of achieving power and the resulting ability to take independent action. Because of its insubstantial nature, it is difficult to characterize and to witness. It may essentially occur over time, and only prolonged observation can help in its understanding (Oakley and Marsden 1984; Moser 1989).

This kind of participation is also known as wide participation, social participation and self-planning in the development literature.

\section{CONCLUSION}

This study suggests that community participation in the development process can take many forms according to the circumstances. However, tourism research hardly mentions different forms of community participation in the TDP. Rather, it is implied that one form of community participation is valid universally. This rigidity in tourism studies may illustrate that tourism research has debated the concept of participatory tourism development approach in isolation and without much connection with general community participation studies that may create better insights and greater maturity for the formulation of policies for community participation in the TDP. For example, participatory studies on rural development, housing, irrigation and Third World development programs suggest that structural, operational and cultural limitations to community participation should be taken into account before initiating any participatory development activity. To ignore these limitations may constitute a danger for the effectiveness and efficiency of a participatory development approach. 
The adaptation of a typology of community participation to tourism development seems to reduce the conceptual vagueness regarding community participation in the TDP by enabling us to label and identify various forms of community participation. In this sense, it may also lead to tourism scholars not using different phrases interchangeably for community participation in the TDP. This appears to be a limitation to the free-will of authors writing on participatory tourism development issues to employ various phrases as a perfect substitution for each other, but it is essential to categorize and clarify forms of community participation in the TDP for the purpose of effectivi scientific communication. Without a typology of community participation in the TDP, politicians, business interests and scholars will continue to use, deliberately or not, different terms interchangeably for community participation in the TDP to achieve their objectives. This has already created a conceptual vacuum and anarchy, a problem with a completely unsatisfactory solution. It is generally agreed amongst social scientists that a necessary preliminary to any systematic study is the construction of a conceptual framework within which reality may be analyzed (Lewis 1979). If a term is being used in several different ways, it diminishes its usefulness for the purposes of scientific communication. In this context, a typology of community participation contributes to the construction of a systematic theoretical framework to improve the effectiveness and efficiency of scientific communication, and it reduces misuse of the term.

Upon re-considering the concept of community participation in the TDP, three main forms or types of community participation in the TDP can be advanced as conceptual vehicles for tourism development policy formulation. Though made at a theoretical level, it is suggested that the broad typology constitute more meaningful guidance than the one rigid form of community participation. Community participation in the TDP can be classified as pseudo-community participation, passive community participation and spontaneous community participation in the context of tourism development. This simple and broad typology can lead one to consider these categories in terms of how tourism as a multi-disciplinary study might contribute to distinctive positions.

This article has intended to open a much needed debate on considering community participation in the TDP as an adaptive categorical term. The logic behind this is that tourist destinations which are at different level of development, have different socio-cultural, economic and political conditions, and have achieved different levels and types of tourism development have unequal potential opportunities and challenges for host community participation in the TDP. Naturally, community participation should take place at different levels, and in different form in these tourist destinations. In this vein, it was not an objective to provide a means for the postulation of concrete prescriptions for community participation in tourism. The key point to emerge from the preceding analyses is that community participation in the TDP 
should be regarded as a categorical term enabling host communities to participate in the TDP in various forms under different circumstances. Obviously, much more research is still needed to clarify how community participation may be initiated and organized. Who will decide on who should participate or who should not participate? What are the limitations to community participation in the TDP particularly in developing countries where planning and development apparatus is highly centralized, main democratic institutions hardly exist or are not well-established, and expertise and financial resources needed for community participation are not available? In this context, future research should also examine which participatory techniques should be utilized for noted categories of community participation in the TDP.

The unsatisfactory state of participation theory in tourism development may imply that there is a need to benefit from the insights gained in other community participation fields from where the dominant influences on community participation in the developmental literature have come. Hence, it is suggested that re-connection of participatory tourism studies to developmental studies can improve the theoretical framework of community participation in the TDP. In this vein, this study should be regarded as a necessary preliminary only.

\section{REFERENCES}

Arnstein, R. S. (1969). A Ladder of Citizen Participation. Journal of the American Institute of Planners 35: 216-224.

Arnstein, R. S. (1971). Eight Rungs on the Ladder of Citizen Participation', in Cahn, S. E. and Passett, A. B. (eds.), Citizen Participation: Effecting Community Change. New York: Praeger Publishers, pp. 69-91.

Barber, B. R. (1984). Strong Democracy: Participatory Politics for a New Age. Berkeley: University of California Press.

Benicourt, J. (1982). Popular Participation in Development in Africa'. Assignment Children, 59/ 60:57-77.

Blank, U. (1989). The Community Tourism industry Imperative: The Necessity, The Opportunities, Its Potential. Venture Publishing: State College.

Brohman, J. (1996) New Directions in Tourism for Third World Development. Annals of Tourism Research, 23 (1): 48-70.

Burke, M. E. (1968). Citizen Participation Strategies. Journal of the American Institute of Planners 34 (5): 287-294.

Cahn, S. E. and Cahn, C. J. (1971). Maximum Feasible Participation: A Generai Overview. In Cahn, S. E. and Passett, A. B. (eds.), Citizen Participation: Effective Community Change. New York: Praeger Publishers, pp. 9-66.

Cheema, G. S. (1987). Urban Shelter and Services: Public Policies and Management Approaches. London: Praeger Publishers.

Chetkov-Yanoov, B. (1986). Participation as a Means to Community Co-operation. In Levi, Y. and Litwin, H. (eds.), Community and Cooperatives in Participatory Development. Aldershot: Gower Publishing Company Limited, pp. 21-34.

Cohen, J. M. and Uphoff, N. T. (1980). Participation's Place in Rural Development: Seeking Clarity through Specificity. World Development 8 (3): 213-235. 
Cole, R. L. (1974). Citizen Participation and the Urban Policy Process. Lexington, Ma: DC. Heath.

D' Amore, L. (1983) Guidelines to Planning in Harmony with the Host Community', in Murphy, P. E. (ed.), pp. 135-60, Tourism in Canada: Selected Issues and Options. Western Geographical Series, Volume 21 .

de Kadt, E. (1982). Community Participation for Health: the Case of Latin America. World Development 10 (7): 573:84.

de Kadt, E. (1979). Politics, Planning, and Control. In Tourism Passport To Development?, de Kadt ed., pp. 18-33. Published For The World Bank and UNESCO. Oxford: Oxford University Press

de Vaus, D.A. (1996). Surveys in Social Research. Fourth Edition. London: Allen and Unwin.

Dudley, E. (1993). The Critical Villager: Beyond Community Participation. London: Routledge

Eversley, D. (1973). The Planner in Society: the Changing Role of a Profession. London: Faber and Faber.

Fagence, M. (1977). Citizen Participation in Planning. Oxford: Pergamon Press.

Florin, P. and Wandersman, A. (1990) An Introduction to Citizen Participation, Voluntary Organizations, and Community Development - Insights for Empowerment through Research. American journal of Community Psychology, 18 (1): 41-54.

Getz, D. (1983). Tourism, Community Organization and the Social Multiplier. Leisure, Tourism and Social Change, Congress Proceedings of the Intemational Geographical Union Commission of the Geography of Tourism and Leisure, 2: 85-99.

Godschalk, D. R. (1972). Participation, Planning, and Exchange in Old and New.

Greertz, C. (1973). Ideology as a Cultural System. In Greertz, C. (ed.), The Interpretation of Cultures. New York: Basic Books, pp. 193-229.

Gunn, C. A. (1988). Tourism Planning. Second Edition. New York: Taylor and Francis.

Hall, C. M. and Jenkins, M. J. (1995), Tourism and Public: Policy. London: Routledge.

Hall, C. M. (1994). Tourism and Politics: Policy, Power and Place. Chichester: John Wiley and Sons.

Haywood, K. M. (1988). Responsible and Responsive Tourism Planning in the Community. Tourism Management 9 (2): 105-118.

Hillery, G. A. (1955). Definitions of Community: Areas of Agreement. Rural Sociology 20: 111123.

Hughes, A. (1985). Alternative Forms and Levels of Participation: a General Survey. In Popular Participation in Planning for Basic Needs, Lisk, F. ed., pp. 52-96. Cambridge: The University Press,

Hunter, C. (1997). Sustainable Tourism as an Adaptive Paradigm. Annals of Tourism Research 21 (4): 850-867.

Inglehart, R. (1971). The Silent Revolution in Europe: Inter-Generational Change in PostIndustrial Societies. American Political Science Review 65: 991-1017.

Inskeep, E. (1988). Tourism Planning. Journal of the American Planning Association 54 (3): 360-371.

Inskeep, E. (1991). Tourism Planning, An Integrated And Sustainable Development Approach. New York: Van Nostrand Reinhold.

Inskeep, E. (1994). National and Regional Tourism Planning. A World Tourism Organization (WTO) Publication. London: Routledge.

International Institute of Tourism Studies (1991). Global Assessment of Tourism Policy. Washington: The George Washington University.

Jamal, B. T. and Getz, D. (1995). Collaboration Theory and Community Tourism Planning. Annals of Tourism Research 22 (1): 186-204.

Joppe, M. (1996) Sustainable Community Tourism Development Rivisited. Tourism Management, $17(7): 475-479$.

Keogh, B. (1990). Public Participation in Community Tourism Planning. Annals of Tourism Research 17: $449-65$. 
Law-Yone, H. (1982). Games for Citizen Participation. Simulation and Games, 13(1):51-62.

Leiper, N. (1990). Tourism System, Occasional Paper 2. Auckland, New Zealand: Massey University.

Lisk, F. (1985). Editor's Introduction. In Popular Participation in Planning for Basic Needs; Lisk, F. ed. ,pp. 1-14. Cambridge: The University Press.

Lewis, G. J. (1979). Rural Communities. London: Newton Abbot, North Pomfret (VT).

Midgley, J. (1986). Community Participation: History, Concepts and Controversies', Midgley, J. , in association with Hall, A.; Hardiman, M. and Narine, D. Community Participation, Social Development, and the State. London: Methuen, pp. 13-43.

Midgley, J. Hall, A.; Hardiman, M. and Narine, D. (1986) Preface. In Community Participation, Social Development, and the State. Midgley, J., ed., in association with Hall, A.; Hardiman, M. and Narine, D. London: Methuen, pp. vii-ix.

Morgan, L. M. (1993). Community Participation in Health: The Politics of Primary Care in Costa Rica. Cambridge: Cambridge University Press.

Moser, C. (1989). Community participation in urban projects in the Third World. Progress in Planning 32(p2):73-133.

Murphy, P. E. (1985). Tourism A Community Approach. New York: Methuen.

Murphy, P. E. (1983). Tourism as a Community Industry. Tourism Management 4 (3): 180-193.

Oakley, P. (1991). The Concept of Participation in Development. Landscape and Urban Planning, 20 (1-3): 115-122.

Oakley, P. and Marsden, D. (1984). Approaches to Participation in Rural Development. Geneva: International Labour Office.

Olson, M. (1965). The logic of Collective Action. Cambridge, Ma: Harvard University Press.

Partridge, P. H. (1970). Some Notes on the Concept of Power. In Contemporary Political Theory, de Crespigny, A. and Westheimer, A., eds. New York: Atherton Press.

Pateman, C. (1970). Participation and Democratic Theory. Cambridge, England: Cambridge University Press.

Pearce, P. L., Moscardo, G. and Ross, G. F. (1996). Tourism Community Relationships. Oxford: Elsevier Science Ltd.

Pearse, A. and Stiefel, M. (1980). Debaters' Comments on Inquiry into Participation: A Research Approach. Popular Participation Programme Occasional Paper, Report No. 80.5. Geneva: United Nation Research Institute for Social Development.

Prentice, R. (1993). 'Community-Driven Tourism Planning and Residents' Preferences', Tourism Management, 14 (3): 218-27.

Rajakutty, S. (1991). Peoples Participation in Monitoring and Evaluation of Rural Development Programmes: Concepts and Approaches. Journal of Rural Development, 10(1): 35-53.

Reed, M. (1997). Power Relations and Community-Based Tourism Planning. Annals of Tourism Research 24 (3): 566-591.

Richardson, A. (1983). Participation: Concepts in Social Policy One. London: Routledge and Kegan Paul.

Ritchie, J. R. Brent (1988). Consensus Policy Formulation in Tourism: Measuring Resident Views Via Survey Research. Tourism Management 9 (3): 199-212.

Ryan, C. and Montgomery, D. (1994). 'The Attitudes of Bakewell Residents to Tourism and Issues in Community Responsive Tourism', Tourism Management, 15 (5): 358-369.

Rosenow, J. and Pulsipher, G. L. (1979). Tourism The, Good, Bad and Ugly. Nebraska: Media Productions and Marketing Inc. 
Santhanam, M. L. (1993). Community Participation for Sustainable Development. Indian Journal of Public Administration, XXXIX (3): 413-423.

Schierow, L. J. and Chesters, G. (1983). Enhancing the Effectiveness of Public Participation in Defining Water Resource Policy. Water Resources Bulletin 19 (10): 107-114.

Selin, S., and Beason, K. (1991). Interorganizational Relations in Tourism. Annals of Tourism Research 18:639-652.

Sewell, W. R. D. and Coppock, J. T. (1977). A Perspective on Public Participation in Planning. In Public Participation in Planning, Swell, W. R. D. and Coppock, J. T eds., pp. 2-14. London: John Willey and Sons.

Sherraden, M.S. (1991). Policy Impacts of Community Participation -Health Services in Rural Mexico. Human Organization 50(3): 256-263.

Simmons, D. G. (1994). Community Participation in Tourism Planning. Tourism Management, 15 (2) $98-108$.

Smith, D. H. (1980). Participation in Social and Political Activities. San Francisco: Jossey-Bass.

Smith, L. (1981). A Model for the Development of Public Participation in Local Authority Decision - Making', in Jones, D. and Smith, L., Deprivation, Participation, and Community Action. London: Routledge, pp. 1-36.

Stone, L. (1989). Cultural Cross-roads of Community Participation in Development: a case from Nepal. Human Organization 48(3):206-13.

Taylor, G. (1995). The Community Approach: Does It Really Work?', Tourism Management 16 (7): 487-89.

Tosun, C. (2000). 'Limits to Community Participation in the Tourism Development Process in Developing Countries'. Tourism Management, 21 (6): 613-633.

Tosun, C. (1998). 'Roots of Unsustainable Tourism Development at the Local Level: the Case of Urgup in Turkey', Tourism Management, 19 (6): 595-610.

Tosun, C. and Jenkins, C. L. (1996). Regional Planning Approaches to Tourism Development: The case of Turkey. Tourism Management 17 (7): 519-531.

United Nations (1975). Popular Participation in Decision Making for Development. New York: United Nations

United Nations (1981). Popular Participation as a Strategy for Promoting Community-Level Action and National Development. Department of International Economic and Social affairs. New York: United Nations.

Verba, S. (1967). Democratic Participation. The Annals of the American Academy of Political and Social Science 373: 53-78.

Verba, S. and Nie, N. H. (1972). Participation in America. New York: Harper and Row.

Wadersman, A. (1981). A Framework of Participation in Community Organizations. The Journal of Applied Behavioral Science 17 (1): 27-58.

Wilkins, J. and Passett, A. B. (1971). Introduction: Citizen participation. In Citizen Participation: Effective Community Change, Cahn, S. E. and Passett, A. B. eds., pp. 1-9. New York: Praeger Publishers.

Willis, K. (1995). Imposed Structures and Contested Meanings - Politics of Public Participation. Australian Journal of Social lssues 30 (2): 211-227.

Wolfe, M. (1982). Participation in Economic Development: A Conceptual Framework. Assignment Children 59/60: 79-109.

World Travel and Tourism Council Report (1995). Travel and Tourism: A New Economic Perspective, Pergamon, Oxford. 